\title{
Lacrimal Gland Carcinoma Pathologic TNM Finding v8
}

National Cancer Institute

\section{Source}

National Cancer Institute. Lacrimal Gland Carcinoma Pathologic TNM Finding v8. NCI

Thesaurus. Code C140778.

A pathologic finding about one or more characteristics of lacrimal gland carcinoma, following the rules of the TNM AJCC v8 classification system. 